\title{
RISK FACTORS IN PULMONARY TUBERCULOSIS TREATMENT FAILURE
}

\author{
Dyan Kunthi Nugrahaeni ${ }^{1}$, Lala Rosmalaningrum ${ }^{1}$ \\ ${ }^{1}$ Public Health Program Study, School of Health Sciences \\ Jenderal Achmad Yani Cimahi, Indonesia \\ Correspondences: Dyan Kunthi Nugrahaeni \\ email: dyankunthi@yahoo,co.id
}

\begin{abstract}
Pulmonary tuberculosis (TB) is a global health problem and has become the leading cause of death. Tuberculosis eradication is inhibited due to the tendency of patients to not complete the TB treatment. The purpose of this study was to determine the relationship between knowledge, nutritional status, oral medication adherence, and family support as risk factors for pulmonary tuberculosis treatment failure. The design of this study is that of case-control, and this study involved samples of pulmonary TB patients who were declared not cured after treatment (14 people), and control samples of pulmonary TB patients who were declared cured ( 28 people). The data were obtained through measurements of nutritional status and interviews, while treatment failure was based on data from the TB 01 form. Data was analysed using univariable and bivariable analyses, and the magnitude of risk factors was based on the odds ratio (OR) and 95\% confidence interval (CI). The results showed that the factors associated with failure of pulmonary TB treatment are knowledge $(\mathrm{p}=0.022 ; \mathrm{OR}=6.6 ; 95 \% \mathrm{CI}=1.48-29.36)$, nutritional status $(\mathrm{p}=$ $0.005 ; \mathrm{OR}=9.16 ; 95 \% \mathrm{CI}=2.11-39.85)$, and medication adherence $(\mathrm{p}=0.003 ; \mathrm{OR}=11.0 ; 95 \% \mathrm{CI}=2.37$ 54.14), whereas the unrelated factor is family support $(\mathrm{p}=0.47)$. It is recommended to provide counselling, nutritional guidance, medication assistance, and family support to patients during the treatment period for pulmonary tuberculosis.
\end{abstract}

Keywords: treatment failure, knowledge, nutritional status, compliance

\begin{abstract}
ABSTRAK
Tuberkulosis paru merupakan masalah kesehatan dunia dan menjadi penyebab kematian utama karena penyakit infeksi tunggal. Pemberantasan tuberkulosis terkendala akibat perilaku penderita yang tidak patuh menjalani pengobatan TB. Penelitian bertujuan mengidentifikasi faktor resiko terjadinya kegagalan pengobatan penyakit tuberkulosis paru berdasarkan variabel pengetahuan, status gizi, kepatuhan menelan obat, dan dukungan keluarga sebagai. Desain penelitian menggunakan kasus kontrol, kasus adalah penderita tuberkulosis paru yang gagal setelah pengobatan selama 6 bulan sebanyak 14 orang, sedangkan penderita tuberkulosis paru yang dinyatakan sembuh sebagai kontrol sebanyak 28 orang. Data kegagalan pengobatan berasal dari form TB 01, status gizi berdasarkan pengukuran IMT sedangkan variabel pengetahuan, kepatuhan minum obat dan dukungan keluarga dengan wawancara. Analisis data secara univariabel dan bivariabel, besar resiko berdasarkan nilai odds ratio $(O R)$ dan 95\% confidence interval (CI). Hasil penelitian didapatkan faktor yang berhubungan dengan kegagalan pengobatan TB paru adalah pengetahuan $(p=0,022 ; O R=6,6 ; 95 \% C I=1,48-29,36)$, status gizi $(p=0,005 ; O R=9,16 ; 95 \% C I=2,11-39,85)$ serta kepatuhan menelan obat $(p=0,003 ;$ OR $=11,0 ; 95 \% C I=$ 2,37 - 54,14). Dukungan keluarga tidak berhubungan dengan terjadinya kegagalan pengobatan TB paru $(p=$ 0,46). Disarankan memberikan konseling, meningkatkan status gizi, melakukan pendampingan menelan obat dan adanya dukungan keluarga pada penderita selama menjalani pengobatan tuberkulosis paru.
\end{abstract}

Kata kunci: kegagalan pengobatan, pengetahuan, status gizi, kepatuhan

\section{INTRODUCTION}

\section{INTRODUCTION}

Pulmonary tuberculosis (TB) is one of the most prominent global health issues. In 2016, the number of new patients with positive BTA tests was estimated at 10.4 million with an incidence rate of 142 per 100,000 people (WHO, 2016). The death rate was the second-highest in the world after human immunodeficiency virus/acquired immune deficiency syndrome (HIV/AIDS) as a cause of mortality related to infectious diseases, as it amounted to 1.3 million TB with HIVnegative and 374,000 TB with HIV-positive (Glaziou, Floyd, and Raviglione, 2018). Indonesia is ranked third after India and China with estimated 845,000 new TB 
cases and an incidence rate of 316 per 100.000 people (WHO, 2018).

The World Health Organization (WHO) has recommended various approaches to contain and eradicate tuberculosis around the world by implementing the End Tuberculosis Strategy as well as the Sustainable Development Goals (SDGs) of 2015-2030. They aim to end the global tuberculosis epidemic by reducing the incidence rate to $80 \%$ and reducing mortality by $90 \%$ by 2030 (WHO, 2018).

The main pillar of pulmonary tuberculosis disease control is the efforts to conduct new case identification and treatment within six months using the standard regiment, treatment monitoring, and treating patients through healthcare services through directly observed treatment short-course (DOTS) (WHO, 2018). The WHO recommends DOTS for the reduction and treatment of pulmonary tuberculosis. It emphasizes monitoring medicine intake adherence in accordance with the program until declared cured (Ndwiga, Kikuvi, and Omolo, 2016) with an expectation of a $95 \%$ full recovery rate (Indonesian Ministry of Health, 2011). The range of recovery rates at a global level in 2015 was $83 \%$ for tuberculosis and $78 \%$ for diseases with HIV comorbidity (Glaziou, Floyd, and Raviglione, 2018).

In 2017 the cure rate of pulmonary tuberculosis in was $75.23 \%$ in West Java and $80.39 \%$ in Purwakarta, which was below the expected rate of $85 \%$ (West Java Provincial Health Office, 2017).

The treatment for pulmonary tuberculosis can be inadequate due to various causes, such as irregular consumption of oral medicines, inappropriate regiment, incorrect dosage and medication methods, and discontinuation of treatment by the patient (Nawas, 2010). Failed treatment of tuberculosis may cause bacteria to develop resistance towards anti-tuberculosis medicines such as rifampicin and isoniazid (Indonesian Ministry of Health, 2011).
Patient behavior can trigger the spread and eradication issues of the disease because patients' assumption that it is incurable affects their sense of urgency in seeking medical assistance (Indonesian Ministry of Health, 2016). Knowledge is an essential factor in forming the actions or behavior of an individual (overt behavior). Lack of public knowledge tends to affect the behavior of individuals in seeking information, especially that of the health variety (Notoatmodjo, 2012). A person's knowledge and comprehension regarding health and diseases are crucial in health promotion, especially in ways individuals can lead a healthy lifestyle by maintaining health to avoid contagious illnesses such as pulmonary tuberculosis.

It is estimated that only $5-10 \%$ of people who contract Mycobacterium tuberculosis will become active patients after 1-2 years post-infection or several years after reactivation (Van Crevel, Ottenhoff and van der Meer, 2002). A person who is infected by the tuberculosis bacteria will become an active patient with low immunity against Mycobacterium tuberculosis because the bacteria can rapidly grow and multiply in the human body (Van Crevel, Ottenhoff, and van der Meer, 2002).

The immune system is affected by nutritional status, and most of tuberculosis patients are undernourished. Such a condition can have an impact on the recovery of the disease and the development of clinical manifestations of TB specifically disease (Gupta and Vishvkarma, 2009).

Malnutrition in tuberculosis patients and their lack of weight gain during medication have been reported to be the factors that undermine treatment for pulmonary tuberculosis (Dooley and Chaisson, 2009) and increase tuberculosis comorbidity wth diabetes mellitus (Workneh, Bjune, and Yimer, 2017).

Treatment is considered a failure if the patient is not cured after medication or terminated the medication process. Some 
risk factors that contribute to the failure are positive acid-resistant bacilli tests in the mucus after two months of intensive treatment, medication intake inconsistency, and short treatment records. A high level of bacteria in the body due to chronic infestation, resistance toward antituberculosis drugs, and hospitalization records are risk factors of treatment failure (Dooley et al., 2011).

The treatment a patient must undergo is complicated and burdensome considering its length duration (six months minimum), therefore support from family members is needed during the process (Nawas, 2010). Such support can be in the form of providing relevant information regarding the disease, procuring social and economic assistance, as well as attention and empathy from family members. Families may have an impact on the patient during the medication phase, and their support is essential in maintaining the consistency of the patient's condition whilst undertaking medical treatments (Friedman, 2003).

The purpose of this research was to identify the risk factors in the failure of tuberculosis medical treatment based on the variables of knowledge, nutritional status, oral medication adherence, and family support.

\section{METHODS}

The type of research conducted was observational analytic and used a casecontrol study design. The criterion for sample cases was pulmonary tuberculosis patients who failed treatment after six months, while the criterion for the control cases was patients deemed to be successful after undertaking the same treatment. There were 14 case samples, with a 1:2 ratio for control sampless, and thus there were 28 participants for control samples.

The dependent variable was the failure of the pulmonary tuberculosis treatment, while the independent variables were knowledge, nutritional status, oral medication adherence, and family support.

The knowledge variable measurement was conducted through surveys regarding definitions, causes, symptoms and signs, transmission, prevention, and treatment for tuberculosis. Respondents with at least $75 \%$ correct answers were classified as well-informed. The family support variable was measured through a questionnaire consisting of questions regarding emotional support, information support, and instrumental support. It was considered existent if the score was equal to or above the mean score. The questionnaire for the variable knowledge and family support has been tested for its validity and reliability on the patients with pulmonary tuberculosis.

The nutritional status variable used body mass index based on the bodyweight measured with a bathroom scale, as well as their height measured using a microtoise. The oral medication intake consistency variable used secondary data deriving from the TB 01 form regarding the schedule of their administration. The case and control samples were taken from respondents' medical records, specifically the TB 01 form conveying information on the patients' home address, characteristics, and sputum test results.

The analysis focused on the univariables to discover the characteristics of the respondents based on their age and gender. The results of each variable were displayed in a frequency distribution table. A bivariable analysis was done to analyze the relationship between independent and dependent variables. The odds ratio (OR) calculation and the $95 \%$ confidence interval (CI) determined the scale of the risk of the treatment failure. The significance test used a p-value with a significance level of 0.05 .

The study was carried out under the jurisdiction of the Purwakarta Regency public health centres, namely Jati Luhur, Koncara, Tegalwaru, Darangdang, and Bungursari. It was conducted with full respect for the ethics regulations and other 
applicable terms. It also received authorization from the Health Research Ethical Committee of The School Of Health Sciences Jenderal Achmad Yani (No. 26/KEPK/VI /2016)

\section{RESULTS}

The results showed that most of the treatment failures occurred in patients aged $(50 \%)$, while $36 \%$ of the cases occurred in patients above 40 years old, and the rest occurring in patients below 25 years of age, as shown in Figure 1.

Figure 1. Respondents’'Age Range

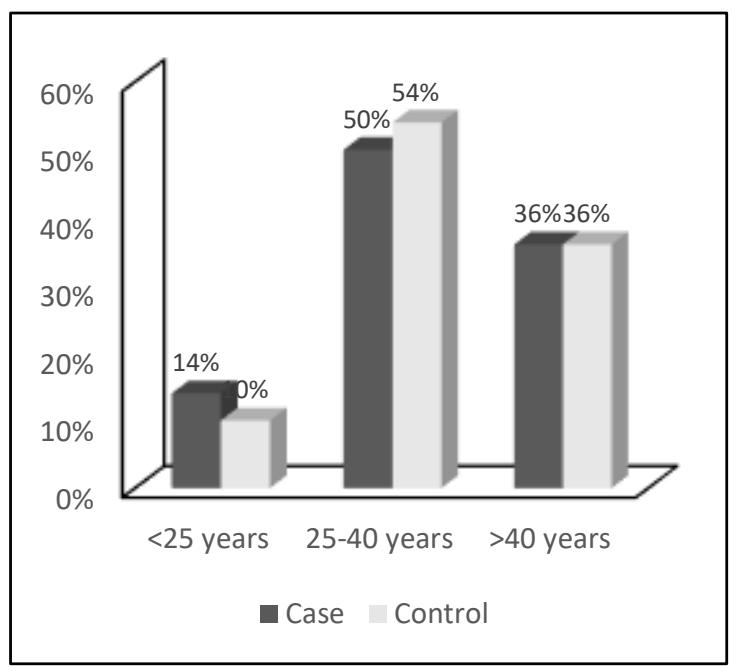

Figure 2 shows that the failure in treatment of pulmonary tuberculosis occurred mostly in women (64\%).

Figure 2. Treatment Failure based on Gender

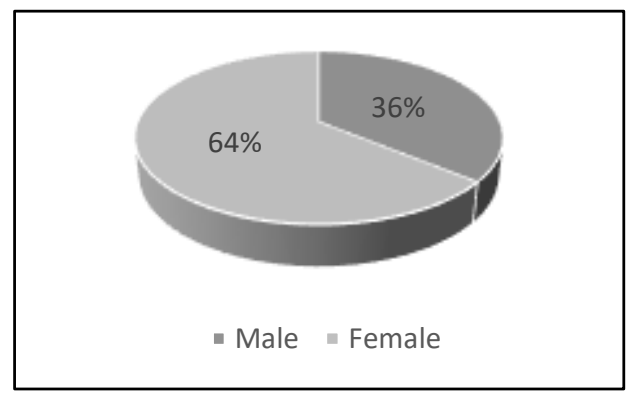

Most of the pulmonary tuberculosis patients who failed the treatment process (78.6\%) had inadequate knowledge regarding the disease. Meanwhile, the minority of healed patients $(35.7 \%)$ lacked understanding of their illness.

The study showed that knowledge is a risk factor in the failure of the treatment of pulmonary tuberculosis $(p=0.22)$. The magnitude of risk factors for failure of pulmonary tuberculosis treatment was measured with the odds ratio (OR) amounting to $6.6(95 \% \mathrm{CI}=1.48-29.35)$, which means that patients with inadequate knowledge had a risk of failure 6.6 times larger compared to those with adequate knowledge.

Table 1. Frequency Distribution of Pulmonary Tuberculosis Treatment Failures due to Knowledge, Nutritional Status, Oral Medication Adherence, and Family Support

\begin{tabular}{|c|c|c|c|c|c|c|}
\hline \multirow[t]{3}{*}{ Variable } & \multicolumn{4}{|c|}{$\begin{array}{c}\text { Treatment Failure } \\
\text { Pulmonary } \\
\text { Tuberculosis }\end{array}$} & \multicolumn{2}{|c|}{ Total } \\
\hline & \multicolumn{2}{|c|}{ Case } & \multicolumn{2}{|c|}{ Control } & \multirow[b]{2}{*}{$\mathbf{n}$} & \multirow[b]{2}{*}{$(\%)$} \\
\hline & $\mathbf{n}$ & $(\%)$ & $\bar{n}$ & $(\%)$ & & \\
\hline \multicolumn{7}{|l|}{ Knowledge } \\
\hline Inadequate & 11 & 78.6 & 10 & 35.7 & 21 & 50 \\
\hline Adequate & 3 & 21.4 & 18 & 64.3 & 21 & 50 \\
\hline \multicolumn{7}{|l|}{$\begin{array}{l}\text { Nutritional } \\
\text { status }\end{array}$} \\
\hline Inadequate & 10 & 71.4 & 6 & 21.4 & 16 & 38.1 \\
\hline Adequate & 4 & 28.6 & 22 & 78.6 & 26 & 61.9 \\
\hline \multicolumn{7}{|l|}{ Oral } \\
\hline \multicolumn{7}{|l|}{$\begin{array}{l}\text { Medication } \\
\text { adherence }\end{array}$} \\
\hline Inconsistent & 11 & 78.6 & 7 & 25 & 18 & 38.1 \\
\hline Consistent & 3 & 21.4 & 21 & 75 & 24 & 61.9 \\
\hline \multicolumn{7}{|l|}{ Family } \\
\hline \multicolumn{7}{|l|}{ Support } \\
\hline Non-existent & 5 & 35.7 & 6 & 21.4 & 11 & 26.2 \\
\hline Existent & 9 & 64.3 & 22 & 78.6 & 31 & 73.8 \\
\hline Total & 14 & 100 & 28 & 100 & 42 & 100 \\
\hline
\end{tabular}

The patients with lower nutritional status based on their body mass index who were unsuccessful in their pulmonary tuberculosis treatment amounted to $71.4 \%$. Meanwhile, only $21.4 \%$ of patients who recovered from pulmonary tuberculosis had lower nutritional status. 
Nutrition is a risk factor in the failure of pulmonary tuberculosis treatment $(\mathrm{p}=0.005)$. Its significance from the OR calculation showed a value of $9.16(95 \% \mathrm{CI}$ =2.1-39.85), which means that undernourished patients had 9.16 times the potential of not being cured compared to those with who were well-nourished.

Table 2. Failure Risk Factors Pulmonary Tuberculosis Treatment

\begin{tabular}{lcc}
\hline \multicolumn{1}{c}{ Variable } & p value & $\begin{array}{c}\text { OR } \\
(\mathbf{9 5} \% \boldsymbol{C I})\end{array}$ \\
\hline Knowledge & 0.022 & 6.6 \\
& & $(1.48-29.35)$ \\
Nutritional status & 0.005 & 9.16 \\
& & $(2.1-39.85)$ \\
Oral Medication & 0.003 & 11.0 \\
Adherence & & $(2.37-51.14)$ \\
Family Support & 0.46 & 2.04 \\
& & $(0.5-8.4)$ \\
\hline
\end{tabular}

Patients who were not cured due to inconsistencies in oral medication adherence amounted to $78.6 \%$. Meanwhile, of all the patients who recovered from pulmonary tuberculosis, only $25 \%$ did not consistently take their anti-tuberculosis drugs.

Adherence in oral medication intake is a risk factor in the failure of pulmonary tuberculosis treatment $(\mathrm{p}=0.003)$, with a magnitude of risk factor for failure of tuberculosis treatment based on OR amounting to 11.0 (95\% CI $=2.37-51.14)$. This means that patients with pulmonary tuberculosis who were not compliant in swallowing anti-tuberculosis drugs were 11 times more at risk of experiencing treatment failure compared to respondents who were compliant.

The patients who failed the treatment and did not receive family support amounted to $35.7 \%$, while only $21.4 \%$ healed without family support. The family support variable was not a risk factor that contributed to the failure of pulmonary disease treatment $(\mathrm{p}=0.46 ; \mathrm{OR}=2.04 ; 95 \%$ $\mathrm{CI}=0.5-8.4$ ).

\section{DISCUSSION}

A pulmonary tuberculosis treatment is considered a failure when it has been conducted for over five months with positive smear test results or when it is discontinued by the patient for more than two consecutive months (considered as a drop out) (Dooley et al., 2011; Indonesian Ministry of Health, 2011). The failure rate treatment at a national level was $0.4 \%$ and the loss to follow up was $5.4 \%$ in 2018 (Indonesian Ministry of Health, 2018).

The treatment success rate or TSR the percentage of tuberculosis cases that have been cured based on the results of bacteriological tests as well as the patient's completion of the medication among the patients treated and reported. The TSR in 2018 was $80.12 \%$ at a national level, which target of $85 \%$ (Indonesian Ministry of Health, 2018). The low success rate needs to be reviewed and evaluated by several parties from various sectors and programs to prevent transmission within a community.

The first factor contributing to the low success rate is patients are not compliant with their treatment schedules, especially in taking their oral medicine. They do not commit to the designated health centers without the consent of the medical staff. Additionally, patients develop resistence towards the anti-tuberculosis drugs provided, especially rifampisin and isoniazid. The second factor is the role of the oral medication supervisors who are not active enough in monitoring and observing the intake. The third factor is the insufficient supply, availability, and storage of the drugs that affect their administration. Patients tend to delay taking them and finally discontinue the treatment. Incorrect storage methods that are not compliant with the procedures may decrease the quality and effectiveness of the drugs (Indonesian Ministry of Health, 2018). 
One of the causes of treatment failure for pulmonary tuberculosis is the medication management that does not comply with standards (e.g., private practices not implementing the DOTS strategies), a lack of effort in finding treatments for the disease, and obstacles in monitoring the treatment, especially for patients from out of town (Endarti et al., 2018).

The Basic Health Research in 2013 showed an increasing prevalence number for pulmonary tuberculosis in the productive age group; however, the number tended to decline in the advanced age group. In line with this study, it was discovered that there was a rise in the cases of the disease in the productive age group, with $50 \%$ of the cases found in the 25-40 age group, $14 \%$ in the age group of under 25 years, and $36 \%$ in the group beyond 40 years of age. The duration of exposure to various risk factors in contracting tuberculosis is highest in the productive age group.

Studies found that treatment failures mostly occur in women (63\%). A study by Nugrahaeni and Malik (2015) supports this claim, stating that women develop higher resistence towards anti-tuberculosis drugs, amounting to $65.4 \%$ of those who develop resistance are women. In the phases of treatment, male patients outnumber that of female, indicating a lower chance for women to receive optimal medical attention which, in turn, affects the rate of recovery from and progression of the disease. A study by Ganapathy et al. (2008) showed that adolescent and adult males received priority in care and attention while being ill, since they were considered their family income earners and must recover quickly to return to their work. Women tend to not disclose problems or seek medication for their health problems as well as postpone medication. Instead, they tend to do so when their discomfort and symptoms are at their worst since they have their own responsibilities in caring for their families (Ganapathy et al., 2008).
The prevalence rate of tuberculosis is higher in men compared to women based on the results of laboratorium tests, since there is a gap of access for healthcare including medical care, health-seeking behavior, and stigma. The low number of women visiting primary healthcare centers and submitting mucus samples for laboratorium tests is due to the difficulties in accessing healthcare, as well as the stigma on female tuberculosis patients. Such negative stigma is more readily accepted by women rather than married men (Allotey and Gyapong, 2008).

The rate of treatment failure is higher in patients with inadequate medical knowledge, especially regarding information on the medication and prevention of tuberculosis. Some principles of pulmonary tuberculosis prevention focus on the provision of knowledge to patients about the disease, its danger and effects, ways of spreading, and efforts in preventing and recuperating from the illness (Danusantoso, 2013). Knowledge is the result of sensing something in one's environment and gaining information that can be used to decide the appropriate action to take (Notoatmodjo, 2012).

$$
\text { Compliance of pulmonary }
$$

tuberculosis patients towards their medication programs is related to their knowledge on the disease and the availability of special education such as counselling with providers of health service facilities (Dooley et al., 2011). A study by Wulandari (2015) showed that such patients with a low level of knowledge were 2.9 times more at risk of not following through with their medication process compared to patients with adequate knowledge.

Efforts in prevention and care for patients who failed their treatment include proper case management as well as intensive education (Dooley et al., 2011). Adequate knowledge of the disease will help the patients in understanding various actions that must be taken for their treatment to reduce the risk of failing the treatment process. Results from a study by 
Mulenga et al. (2010) showed that about $89 \%$ of respondents knew the importance of completing the six-month treatment, and only $55 \%$ of them understood the need for patients to submit their mucus samples for follow-up medication.

Interventions can be made to ensure the implementation of pulmonary tuberculosis prevention and control, namely through advocation to receive support from policymakers regarding strategic plans. Another intervention is to establish a social communication among patients, healthcare providers, medical staff, and society to create an environment conducive for positive perception of the disease, preventive behaviors for its transmission, oral medical treatment monitoring, and campaigns for prevention and eradication of the disease. The third intervention is social mobilisation through counselling for intensive information conveyance to the patients to improve their knowledge and build a more supportive attitude and behavior towards prevention, controlling, and treatments (Indonesian Ministry of Health, 2011).

A risk factor for treatment failure, among others, is nutritional status. Patients who do not gain enough weight (less than $10 \%$ ) after two months of medication are at risk of failing the treatment (Dooley et al., 2011). One of the causes of such failure is that patients are undernourished, as proven by a study by Gupta and Vishvkarma (2009), which showed how pulmonary tuberculosis patients tend to have lower nutrition than healthy people. Infections in the body like tuberculosis may lower appetite and lead to malabsorption of nutrition and micronutrients, leading to changes in the physical metabolism. Malnutrition in such patients may cause a delay in their recovery process during medication.

The inadequate nutritional status causes the immune system to weaken and the Mycobacterium tuberculosis bacteria can multiply easily, thus the delay in the recuperation. Nutrition defficiency in the patients such as malnutrition and protein imbalance will affect the immune system (Glaziou, Floyd, and Raviglione, 2018), causing immunocompetence or lowering the ability of the body to fight against bacteria, especially affecting the maturation of $\mathrm{T}$ cells (T-lymphocyte) and causing the activation of alveolar macrofag (Gupta and Vishvkarma, 2009), when the activation of the two entities is key to immunity against and eliminating intercellular infection like the Mycobacterium tuberculosis bacteria (Baratawidjaja and Rengganis, 2014). Most of the patients $(80 \%)$ who did not reach cure have inadequate nutritional status $(\mathrm{p}=$ 0.002) (Murtantiningsih and Wahyono, 2010).

Treatment failures in curing pulmonary tuberculosis patients are caused by various risk factors, namely the availability of anti-tuberculosis drugs, the dosage and combination of drugs, shorter medication duration, and compliance with or consistency in the treatment (Crofton, 2002; Danusantoso, 2013).

This research also found that noncompliancy in taking oral medication is a risk factor of treatment failure for pulmonary tuberculosis. Patients can be completely cured when they consumes the drugs routinely, except for patients who develop resistence towards potent medicine such as isoniazid and rifampisin. Inconsistency in taking the medicine, or discontinued treatment without confirmation to medical staff for more than two months, as well as shorter treatment duration will result in failure (Dooley et al., 2011; Danusantoso, 2013).

Murtantiningsih and Cahyono (2010) found that $92 \%$ of the patients who completed the treatment were declared to be free from the disease, and this proved the correlation between consistency in the medication process and recovery from the illness ( $p=0.005)$. Research by Ndwiga, Kikuvi, and Omolo (2016) showed that knowledge regarding the anti-tuberculosis medicine swallowing frequency had a significant relation $(p=0.004)$ with the 
completion of the treatment using the DOTS strategies.

Oral medication adherence is the level of compliance of a patient in swallowing medication based on the standard procedure provided by medical staff, such as a physician or paramedic (Niven, 2002). Compliance with medication can be used as an intervention method to reduce obstacles in providing care for and prevention of the disease. Its obstructing factors in the long term are the characteristics and the financial state of the patient, the healthcare provision system, and considerations regarding the medical condition of the patient (Garner, Smith, and Volmink, 2007).

Some possible interventions that can be used to increase medication adherence among pulmonary tuberculosis patients are educating the patients regarding health issues, as well as caring for and medicating against the disease (Garner, Smith, and Volmink, 2007). These interventions are done with the expectation that their improvements will help alter the patient's behavior, especially in taking the oral medicine. Muniroh, Aisah, and Mifbakhuddin (2013) found that oral medication adherence is a deciding factor in the success of the medication $(p=0.001)$.

Supervision in medicating
pulmonary tuberculosis patients is necessary, especially in ensuring that they take medicine during the intensive medication phase (the first two months after diagnosed as positive) and the later stages. A medical supervisor from a medical team or another competent member should oversee the intake (Indonesian Ministry of Health, 2011).

Non-compliance treatment in patiens with pulmonary tuberculosis has a negative impact on the health of the patients, namely prolonged infection, resistance towards the drugs, relapse, and death (Verma et al., 2019). Patients receiving improper or inadequate treatment are prone to developing resistance towards oral-antituberculosis drugs (Dooley et al.,
2011; Dean, Cox, and Zignol, 2017). Results from Nugrahaeni and Malik (2015) showed that pulmonary tuberculosis patients who develop resistance to antituberculosis drugs due to inadequate medication amounted to $96.2 \%(\mathrm{p}=0.001$; $\mathrm{OR}=40.95 \% ; \mathrm{CI}=4.66-343.14)$. This means that inadequate treatment of pulmonary tuberculosis has 40 times the risk of resistance with antituberculosis drugs.

An intervention model to ensure treatment adherence in patients with pulmonary tuberculosis at the social and familial category is the involvement of family members or society to remind and encourage patients to complete the medication program and reduce the stigma surrounding pulmonary tuberculosis disease (Garner, Smith, and Volmink, 2007). This study showed that a small percentage of pulmonary tuberculosis patients did not receive support from their families, resulting in patients disregarding the significance of treatment. This study had similar results as previous studies conducted by Murtaningsih and Wahyono (2010), which found that there was no relationship between family support with the healing process of pulmonary tuberculosis $(\mathrm{p}=0.773)$, as well as Muniroh (2013) $(\mathrm{p}=0.073)$.

The consistency of pulmonary tuberculosis treatment is influenced by family support, including the monitoring of swallowing oral medication of antituberculosis drugs and medication properly. However, such support, especially for supervising oral medicine intake, improved the patient's consistency and their cure rate when done correctly (Murtantiningsih and Wahyono, 2010). The supervisory role included the responsibility to remind the patients about their intake schedule provided by the designated medical staff of their designated health centers (Indonesian Ministry of Health, 2011) and to complete the program. One of the requirements of being a supervisor is that the person must be familiar and trustworthy for the patient, 
located not far from their residency, and be able to function voluntarily (Kaulagekarnagarkar, Dhake, and Jha, 2012). Results from a study by Septia et al. (2013) showed that positive family support would affect the oral medication adherence among pulmonary tuberculosis patients $(\mathrm{p}=$ 0.036).

Family is one of the deciding factors in the health status of its members, and it is an essential element concerning the successful completion of medication programs (Friedman, 2003). In general, family support for pulmonary tuberculosis patients is in the form of appreciation and emotional support. In contrast, instrumental support relates to assistance in finance, time, and the environment, since the cost of the treatment for the disease is considered as the responsibility of the government (Muniroh, Aisah, and Mifbakhuddin, 2013).

Family members can show their support by accompanying the patients while getting prescriptions, consultations, or health check ups at health centers. They should also remind them to regularly take their drugs and of the importance of completing the program, as well as monitor their diet which should regulate their nutrition, menu, and eating pattern (Kaulagekar-nagarkar, Dhake, and Jha, 2012).

\section{CONCLUSION}

The risk factors in the failure of pulmonary tuberculosis treatment based on this study are knowledge, nutritional status, and oral medication adherence. Based on the results of this study, the first two factors were mostly found to be inadequate, and most respondents failed to be consistent in taking their medicine.

Only the minority of patients who failed in their medication program did not gain support from their families, and thus the reason for considering the factor has an insignificant contribution to the treatment failure. It is recommended that patients are given education on health through counselling to raise awareness about the disease, especially information on medication, controlling the disease, and the correct method of patient-handling for their family, their community, or healthcare providers. Furthermore, increasing their nutritional status as well as maintaining adequate nourishment is crucial to allow their immune system to fight against Mycobacterium tuberculosis from hampering the recuperation process.

Another recommendation is that there should be supervision in the use of anti-tuberculosis drugs to ensure that patients comply with the dosage and the schedule. This can be achieved by having cooperation among the designated medical staff from the health centers that implement DOTS, family members, and the surrounding community.

The family members should be involved as partners alongside medical supervisors in the monitoring of the oral medicine intake to ensure that it is consistent. They should also observe and aid in improving the nutritional status of patients to accelerate the recuperation process. Intensive education is equally important for both patients and their families and can be provided through counselling of the medication process and disease control.

\section{REFERENCE}

Baratawidjaja, K. and Rengganis, I. (2014) Imunologi Dasar. 12th edn. Jakarta: Balai Penerbit Fakultas Kedokteran Universitas Indonesia.

Crofton (2002) Tuberkulosis Klinis. Jakarta: PT. Widya Medika.

Danusantoso, H. (2013) Buku Saku Ilmu Penyakit Paru. Kedua. Jakarta: EGC press penerbit Kedokteran.

Dean, A., Cox, H. and Zignol, M. (2017) 'Epidemiology of Drug-Resistant Tuberculosis', Advances in experimental medicine and biology, 1019, pp. 209-220. https://doi.org/10.1007/978-3-319- 
64371-7_11

Dooley, K. E. et al. (2011) 'Risk factors for tuberculosis treatment failure, default, or relapse and outcomes of retreatment in Morocco', BMC Public Health. BioMed Central Ltd, 11(1), p. 140 . https://doi.org/10.1186/1471-245811-140

Dooley, K. E. and Chaisson, R. E. (2009) 'Tuberculosis and diabetes mellitus: convergence of two epidemics', The Lancet infectious diseases. NIH Public Access, 9(12), p. 737. https://doi.org/10.1016/S14733099(09)70282-8

Endarti, A. T. et al. (2018) 'Situasi Tuberkulosis di Empat Kabupaten / Kota di Pulau Sumatera dan Banten Tuberculosis Situation in Four Districts in Sumatera Island and Banten', pp. 108-118.

Fadila, R. N. and Riono, P. (2014) 'Pengaruh Rejimen terhadap Ketidakpatuhan Berobat Tuberkulosis', Jurnal Kesehatan Masyarakat Nasional, 9, pp. 107112.

Friedman (2003) Keperawatan Keluarga, Teori dan Praktik. Jakarta: Penerbit Buku Kedokteran EGC.

Garner, P., Smith, H. and Volmink, J. (2007) 'Perspectives Promoting adherence to tuberculosis treatment', 035568(December 2006), pp. 2006-2008. https://doi.org/10.2471/BLT.

Glaziou, P., Floyd, K. and Raviglione, M. C. (2018) 'Global Epidemiology of Tuberculosis'.

Gupta, K. buhari and Vishvkarma, S. (2009) 'Tuberculosis and nutrition', Lung India, 26(1), pp. 9-16.

Indonesian Ministry of Health (2011) Pedoman Nasional penanggulangan tuberrculosis. Edisi 2. Jakarta.

Indonesian Ministry of Health (2018) Infodatin Pusat Data dan Informasi Kementrerian Kesehatan RI.
Jakarta.

Kaulagekar-nagarkar, A., Dhake, D. and Jha, P. (2012) 'Perspective of tuberculosis patient on family support and care in rural Maharashtra', 411007, pp. 224-230.

Mulenga, C. et al. (2010) 'Management of pulmonary tuberculosis patients in an urban setting in Zambia: a patient' s perspective', BMC Public Health. BioMed Central Ltd, 10(1), p. 756. https://doi.org/10.1186/1471-245810-756

Muniroh, S., Aisah, S. and Mifbakhuddin (2013) 'Faktor-faktor yang berhubungan dengan Kesembuhan Penyakit Tuberculosis (TBC) Paru di Wilayah Kerja Puskesmas Mangkang Semarang Barat', Jurnal Keperawatan Komunitas, 1(1), pp. 33-42.

Murtantiningsih and Wahyono, B. (2010) 'Faktor-faktor yang berhubungan dengan kesembuhan penderita tuberkulosis paru', Jurnal Kesehatan Masyarakat, 6(1), pp. 44-50.

https://doi.org/10.15294/kemas.v6i 1.1751

Nawas, A. (2010) 'Penatalaksanaan TB MDR Dan Strategi DOTS Plus', Jurnal Tuberkulosis Indonesia, $7(10-17)$.

Ndwiga, J. muriuki, Kikuvi, G. and Omolo, jared odhiambo (2016) 'Factors influencing knowledge on completion of treatment among TB patients under directly observed treatment strategy, in selected health facilities in Embu County, Kenya', 8688, pp. 1-8. https://doi.org/10.11604/pamj.2016 .25.234.8761

Niven (2002) An Introduction for nurses and other health care Professionals. alih Bahas. Jakarta: Penerbit Buku Kedokteran EGC.

Notoatmodjo, S. (2012) Promosi Kesehatan dan Perilaku Kesehatan. Jakarta: 
Rineka Cipta.

Nugrahaeni, D. K. and Malik, U. S. (2015) 'Analisis Penyebab Resistensi Obat Anti Tuberkulosis', Jurnal Kesehatan Masyarakat, 11(1), pp. 8-15.

https://dx.doi.org/10.15294/kemas. v11i1.3341

Septia, A., et al. (2013) 'Hubungan dukungan keluarga dengan kepatuhan minum obat pada penderita tb paru', pp. 1-10.

Verma, M. et al. (2019) 'Making the case : developing innovative adherence solutions for the treatment of tuberculosis', pp. 1-4. doi: 10.1136/bmjgh-2018-001323.

West Java Provincial Health Office (2017) Profil Kesehatan Jawa Barat. Bandung.

WHO (2016) Global Tuberculosis Report 2015. Geneva.

WHO (2018) Tuberculosis profile. Geneva. Van Crevel, R., Ottenhoff, T. H. M. and van der Meer, J. W. M. (2002) 'Innate immunity to Mycobacterium tuberculosis.', Clinical microbiology reviews, 15(2), pp. 294-309.

https://doi.org/10.1128/CMR.15.2.2 94

Workneh, M. H., Bjune, G. A. and Yimer, S. A. (2017) 'Prevalence and associated factors of tuberculosis and diabetes mellitus comorbidity: A systematic review', pp. 1-25.

Wulandari, D. H. (2015) 'Analisis FaktorFaktor yang Berhubungan dengan Kepatuhan Pasien Tuberkulosis Paru Tahap Lanjutan Untuk Minum Obat di RS Rumah Sehat Terpadu Tahun 2015', 2, pp. 17-28. 